\title{
The doctrine on God, as demonstrated and confessed in the Heidelberg Catechism
}

\author{
Author: \\ Carel F.C. Coetzee ${ }^{1}$ \\ Affiliation: \\ ${ }^{1}$ Systematic Theology, Faculty \\ of Theology, North-West \\ University, South Africa \\ Correspondence to: \\ Carel Coetzee \\ Email: \\ callie.coetzee@nwu.ac.za \\ Postal address: \\ PO Box 20655, Noordbrug \\ 2522 , South Africa \\ Dates: \\ Received: 15 Feb. 2013 \\ Accepted: 17 Apr. 2013 \\ Published: 14 Aug. 2013 \\ How to cite this article: \\ Coetzee, C.F.C., 2013, \\ 'The doctrine on God, as \\ demonstrated and confessed \\ in the Heidelberg Catechism', \\ In die Skriflig/In Luce Verbi \\ 47(2), Art. \#703, 10 pages. \\ http://dx.doi.org/10.4102/ \\ ids.v47i2.703
}

\section{Copyright:}

(C) 2013. The Authors. Licensee: AOSIS

OpenJournals. This work

is licensed under the

Creative Commons

Attribution License.

Read online:
Although the Heidelberg Catechism (HC) does not deal with a systematic doctrine on God and although there are not many sources available on the specific subject, it is a most important subject when dealing with the theology of the HC (W. van 't Spijker). Due to the prescribed length of the article, it only focuses on two aspects of the doctrine on God, namely the Trinity and the relationship between God and the cosmos (reality). Futhermore, today there is an emphasis on a new concept of God, known as Panentheism. In this concept, God and his creation are identified with each other. In the South African context, the article deals very shortly with the viewpoints of Spangenberg, Van Aarde and Müller in this regard. The God confessed in the HC is the triune God: Father, Son and Holy Spirit. In the closest and most logical coherence with this, the HC confesses the deity of Christ and of the Holy Spirit. The $\mathrm{HC}$ also proceeds from the premise of the historical, bodily resurrection of Christ from the dead. As far as the relationship between God and creation is concerned, the HC, in agreement with the church of the first centuries, confesses and teaches a personal God, the Father of Jesus Christ, who for the sake of Christ is the Father of the elect. This God is the almighty creator of heaven and earth. He lives in a covenant relationship with his creation, which he sustains and governs at every moment. He is both transcendent and immanent.

Die Godsbegrip soos dit deur die Heidelbergse Kategismus begrond en bely word. Alhoewel die Heidelbergse Kategismus (HK) nie 'n sistematiese Godsleer bevat soos sommige van die ander belydenisskrifte nie en bronne oor die spesifieke onderwerp betreklik skaars is, is dit tog een van die belangrikste onderwerpe wanneer daar oor die teologie van die HK gehandel word (W. van 't Spijker). Vanweë die voorgeskrewe lengte, word daar in hierdie artikel slegs op twee aspekte van die Godsleer gefokus, naamlik die Drie-eenheid en die verhouding van God tot die kosmos (werklikheid). Hierdie twee aspekte is juis besonder relevant in die lig van standpunte wat die leer van die Drie-eenheid in gedrang bring deur onder andere die Godheid van Christus en sy liggaamlike opstanding te bevraagteken. Verder word daar vandag gepleit vir 'n nuwe Godsbegrip, bekend as Panenteïsme, waardeur die grens tussen God en sy skepping vervaag. In die Suid-Afrikaanse konteks word hier kortliks aandag aan die standpunte van van Spangenberg, Van Aarde en Müller gegee. Die God wat in die HK bely word, is die drie-enige God: Vader, Seun en Heilige Gees. In die nouste en logiese samehang hiermee bely die HK die Godheid van Christus en van die Heilige Gees. Wat die verhouding tussen God en die skepping betref, bely en leer die HK, in ooreenstemming met die kerk van die eerste eeue, 'n persoonlike God - die Vader van Jesus Christus wat ter wille van Christus die Vader is van die uitverkorenes. Hierdie God is die almagtige Skepper van hemel en aarde. Hy leef in 'n verbondsverhouding met sy skepping wat Hy elke oomblik onderhou en regeer. Hy is tegelyk transendent en immanent.

\section{Introductory remarks}

1. It is part of the problem statement pertaining to the title of this article that not many available sources deal with this specific subject. Most deal with the Heidelberg Catechism (HC) chronologically, following the sequence of Lord's Days. The content is not dealt with 'through all the loci in dogmatics ordered sequentially as with the Belgic Confession' (Jacobs 1959:60; cf. Jonker 1994:109). ${ }^{1}$

2. The HC therefore does not have a systematic doctrine of God. Different aspects of the doctrine are found throughout and need to be researched. In a sense, this makes it challenging to deal with the topic in a single article.

3. The HC forms part of the dogma of the church, as its doctrines appeal to the Word of God as being normative (Van Genderen \& Velema 2008:1). What the church teaches in accordance

1.The book of Beeke and Ferguson (1999), however, gives a valuable harmony of six reformed confessions (the Three forms of Unity, the Westminster Confession and the Westminster shorter and larger Catechism) regarding the following doctrines: the doctrines of God, anthropology, Christology, soteriology, ecclesiology and eschatology. 
with Scripture, begs acceptance. The church's dogmatic pronouncements therefore, based on the Word of God, allows it to make pronouncements on what ought to be believed (Van Genderen \& Velema ibid:2).

4. The HC, though, is the fruit of theology or dogmatics, which serves the church in formulating dogma. The question therefore is also upon which theology the HC is founded. This question will be dealt with later on in this article.

5. The specific nature and character of the HC must be kept in mind. Verboom (2012) states that the heartbeat of the HC is its Christology. 'Jesus Christ, his person and his work form the theological center of this textbook' (Verboom ibid:115). Its Christology is better understood to be soteriological. A clear example of this is found in question and answer 26, to be dealt with later in this article.

\section{Relevance}

The topic of this article is nevertheless regarded as one of the most important when dealing with the theology of the HC (Van 't Spijker 2012).

The actuality of the topic is further emphasised by the fact that the doctrine of God is in the centre of contemporary debate. From both a philosophical and theological point of view, many works have recently been published in this regard (cf. inter alia Esterhuyse 2009; Du Toit 2000; Clayton 2000; Moltmann 1985). On the one hand, there is the onslaught from atheism and its propagation of the theory of evolution and evolutionism (cf. inter alia Dawkins 2006). On the other hand, there is the renewed debate regarding the doctrine of the Trinity. The traditional reformed doctrine of the Trinity is not only questioned, but rejected by 'anti-christian' groups, like the Jehovah Witnesses (cf. inter alia Stoker 1994:292299). Regarding the Trinity, the debate is closely related to viewpoints pertaining to the divinity and resurrection of Christ, a debate extending even within traditional Reformed circles in South Africa (cf. inter alia Coetzee 2013; Bosch 2009; Müller 2011; Van Aarde 2001). It is also significant that there is a striking resemblance to seventeenth century positions, mooted in expressions of atheism, arminianism, socinianism and issuing in rejections of the Trinity, which were addressed in 'catechism preaching' (cf. Van den Berg 2012:97-98).

Another facet of the debate regarding the doctrine of God, is a plea for a new God concept (cf. inter alia Muller 2002:12; Müller 2007). This new view of God is expressed in panentheist terms (literally all in God and God in all). ${ }^{2}$ Here the debate deals in particular with the relationship between God and the world (cosmos or creation). Vorster (2006:178) states in this regard that a new millennium has dawned in Africa, with the age-old question of the transcendence and immanence of God back on the theological agenda.

2.Cf. Coetzee (2013) for a more comprehensive overview of this debate, especially in the South African context.
As far as panentheism is concerned, Cooper (2007:18) states that: 'In brief, panentheism affirms that although God and the world are ontologically distinct and God transcends the world, the world is "in" God ontologically.'

As reasons for the insistence on panentheism, the following can be mentioned inter alia:

- A shift from theocentrism to anthropocentrism (Wentsel 1987:116).

- Postmodernism with its emphasis on pluralism (Ferreira 2009:357).

- A changed worldview. Piet Muller (2002:12) suggests that the theistic view of God dates from a time when humankind believed in a three-storeyed cosmos: the earth in the middle, hell beneath and heaven above. According to Muller (ibid:12), this theistic way of thinking about God became outdated with the development of 'new physics' and astrophysics. Julian Müller (2007) is also convinced that the changed worldview is the main reason necessitating a 'new understanding of God'. In addition, he refers to the claims of evolutionary viewpoints and states that if one believes that the cosmos is the product of an evolutionary process, our world and humanity are reduced to evolutionary chance (Müller 2011:152). With such a total change in our view of the cosmos, it then becomes untenable to maintain traditional views about God.

Over against the viewpoints of Muller and Müller, Van Wyk (2003:352) is of the opinion that our view of God does not depend on our worldview. On the contrary, our worldview depends on our view of God. If our view about God has to change every time our worldview changes, then, in essence, we are not dealing with God anymore.

\section{Limitations}

It is impossible to do all the aspects of the doctrine of God justice in a single article as it is generally dealt with in the theological discipline of dogmatics. In the light of what was said in point 2 under 'Introductory remarks', this article will limit itself to two aspects alone, namely the being of God as the triune God, and the relationship between God and creation. Aspects like the attributes of God and his counsel are not dealt with explicitly.

Before dealing with these two aspects, it is necessary to briefly deal with the theology of the HC.

\section{The theology of the Heidelberg Catechism}

Thorough research has been done over the years regarding the theology on which the HC was founded (cf. inter alia Steenkamp 1989; Engelbrecht 1989; Schulze 1993, 1994; Klooster 1994; Verboom 1996, 2012; Bierma et al. 2005; Van 't Spijker 2009). The research was hampered by the fact that documentation pertaining to the acts of the committee and the synod that approved the HC in January 1563 was lost during wars (Schulze 1993:491). Verboom (1996:17), on the other hand, refers to an assertion by 'experts' that the 
archival documents of the process of formulating the $\mathrm{HC}$ were taken to the library of the Vatican after the Palatinate reverted to become Roman Catholic again. ${ }^{3}$

Research clearly establishes the influence of Melanchthon. Furthermore, the composers of the HC made use of the two catechisms of Leo Juda, the Large Catechism (1534) and the Short Catechism (1541), the Catechism of John Calvin (1542), as well as the Large Catechism of J.á Lasco (cf. Verboom 1996:17). Even the clear influence of Luther is not denied (Schulze 1994:199-200). As far as the theological orientation of the (probable) composers is concerned, it is pointed out that there were Calvinists (Ursinus, Olevianus, Tremellius, Boquinus and Dathenus), a follower of Melanchthon (Diller) and a Zwinglian -(Erastus) (Schulze 1993:490). Recently, the importance of the Confession de la foy chrestienne of Beza in framing the HC was also brought to the fore (Verboom 2010:160-161; 2012:124). Bierma et al. (2005:102) also emphasise the influence of Beza.

Finally, the conclusion of this research is virtually unanimous, namely that the confession is the result of the joint work and consensus of the members of the committee with their different theological nuances (Schulze 1993:491). At the same time, the originality of the HC betrays no sign of sito-sito plagiarism (Schulze ibid:495). Verboom (1996:24) declares the $\mathrm{HC}$ as authentically [reformed], whilst at the same time accommodating different theological viewpoints. The unifying element, according to Verboom (ibid:24-25), is responsible for the power of the $\mathrm{HC}$ and the reason why it was so widely acknowledged. Jonker (1994:105) calls the HC the most ecumenical reformed confession, although it should not be understood as ecumenical in the contemporary sense, but as 'reformation ecumenism at its best' (Bierma et al. 2005:77, with reference to Hageman; cf. Klooster 1965). Bierma et al. (ibid:77-78) refer to the historical context of the time and the role that Elector Frederick III played in this regard. Bierma et al. (ibid) state:

How could he as a Lutheran elector confessionally repudiate certain Gnesio-Lutheran, Calvinist and Zwinglian factions in his realm without straying outside the bounds of the Augsburg Confession and thus violating the terms of the Peace of

Augsburg? His answer was the HC. (p. 78)

In conclusion, it can be said that the $\mathrm{HC}$ is an unique creation with its own beauty and clarity (Schulze 1993:494), where the focus was on the common theological ground of leading Protestant theologians of the time (Bierma et al. 2005:102).

The aforementioned also applies to the aspects of the doctrine of God, which is dealt with next.

\section{The only true God - the triune God Introduction}

Barth (1948:49-50) sees the doctrine of God of the HC as opposed to the scholastic theology of the seventeenth

\footnotetext{
3.It will be worth whilst to investigate the statement of Verboom further. If the
documents could be found after four and a half centuries, it will be of tremendous documents could be found after four and a half centuries, it will be of tremendous significance and value.
}

and eighteenth century, as expressed in the Gotteslehre komplizierte Wege eingeschlagen. As far as the doctrine of God, and in particular the Trinitarian doctrine and the doctrines of creation and providence (which will be addressed later) are concerned, Jacobs (1959:83) makes the general statement that confessions of the 16th century did not intend to formulate new theology, but wanted to continue in the vein of early Christian confessions (cf. Jonker 1994:24).

Trinitarian doctrine is explicitly addressed in Lord's Day 8, though it is already significantly present in a spontaneous manner in the first answer, as the introduction to and summary of the rest of the HC:

I ... belong unto Jesus Christ [the Son] ... who so preserves me that without the will of my heavenly Father not a hair can fall from my head ... wherefore by His Holy Spirit He also assures me of eternal life ... (GKSA 2001:33).

In this regard Herrenbrück (1965:50-51) speaks about the Trinitarian-theological engagement (Trinitätstheologische Ansatz) of the HC, and Korn (1963:92) points out that what is true of the first answer, applies to the whole of the confession, namely its trinitarian character and christocentric phrasing (cf. Engelbrecht 1989:633, 635).

\section{Lord's Day $\mathbf{8}^{4}$}

In his commentary on question and answer 24, Ursinus (1886:159) makes the point that the creation is attributed to the Father, redemption to the Son and sanctification to the Holy Spirit, but in each case not to the exclusion of the other two persons of the Godhead. Distinction is made however only to signify the difference and order of actions by the divine persons (Ursinus ibid:160). In the same sense, divine deeds are undivided, but retain the order and way of actions that is unique to each of the persons (Ursinus ibid:160).

It is especially in his commentary on question and answer 25 that Ursinus explains the doctrine of the Trinity more fully. He does so by asking eight questions (Ursinus 1886:161185ff.). With that he broadens the horizon beyond that of the catechism in that he seeks to substantiate evidences for the existence of God from various philosophical and theistic premises and arguments (Ursinus ibid:161-163). He also deals with certain attributes of God, which are not particularly addressed in Lord's Day 8 (Ursinus ibid:163-165).

That there is only one God, is proved from express testimonies of Scripture, according to Ursinus (1886:169-170), with reference to texts such as Deuteronomy 6:4 and 32:39, Isaiah 44:6, as well as 1 Corinthians 8:4. In addition, Ursinus mentions solid reasons (grounds). For example, the revealed testimonies are of a credible nature so as to exclude deception unlike wonders, prophecies and works; he who rules the universe alone, singly manages all things and alone possesses the highest majestic honour attributed to only one; the perfect one can only be one, and only one can be

4.In the commentary on certain articles of the HC hereafter, the commentaries of Ursinus ad Olevianus as two of the key figures in the composition of the $\mathrm{HC}$ are used. 
all-powerful, et cetera. For these reasons (grounds), he also has recourse to certain scriptural texts, for example Isaiah $44: 7$ and $42: 8$, Psalm 71:19, as well as Deuteronomy $4: 32$ (Ursinus ibid:170).

Consequently he deals extensively with the question on how to understand 'essence', 'person' and 'trinity', and how these expressions differ from one another (Ursinus 1886:172-175).

'Essence' (ousia) in this doctrine suggests that which is independently supported by itself and in its entirety not dependent upon anything else outside of it, though it is essentially shared in the nature of being (business or things). God's essence is essentially located in a single person, because the deity or the nature of God is found entirely the same in the three persons (Ursinus 1886:172).

The meaning of 'person' (hupostasis huphistamenon, prosoopon) is associated with something that exists. It has its own existence, is independent, living, sensible, undivided and kept proportionately through means of another object (Ursinus 1886:172).

'Essence' is thus the essential being of God, or the eternal Godhead himself. The person is the way the being of God or the divine essence in each of the three is separately identified (Ursinus 1886:173).

In a further definition of 'person', Ursinus (1886:174) refers almost verbatim to the definition given by Calvin (1966:1.13.6) when he says that 'person' means someone that is independent and distinguished from the other by a fundamentally incommunicable property. ${ }^{5}$

The word trinity (trias), employed by Ursinus (1886:175), indicates that these three persons are distinct by way of singular trinitarian essence of the Godhead.

Ursinus (1886) does not deal separately with the phrase in answer 25, 'because God has so revealed Himself in His Word'. It remains one of the beloved answers in the whole of the HC. Herrenbrück (1965:52) describes it as a virtue of the $\mathrm{HC}$ that, out of all possible definitions, this expression was chosen. In this manner, the catechism undoubtedly resorts to theology as revelation (Herrenbrück ibid:53).

Yet, Ursinus' abundant use of Scripture references shows that the HC professes nothing but what God revealed in his Word. He does this especially in dealing with the question of his recourse to the words essence, persons and trinity and whether they are to be used as they are not found in the Scriptures, to show that we distinguish three persons in one divine being (Ursinus 1886:175-178). According to Ursinus (ibid:176), scriptural exegesis warrants the use of and replacement by common words in daily use that have the same meanings. The battle between the church and heretics

5.Calvin's definition reads as follows: 'By person, then, I mean a subsistence in the Divine essence, - a subsistence which, whilst related to the other two, is distinguished from them by incommunicable properties' (cf. Calvin 1966:1.13.6). is in no way related to the words, but is about doctrine itself: that the eternal Father and the Son and the Holy Spirit are one and the same God, and yet the Father is not the Son or the Holy Spirit and the Holy Spirit is not the Father or the Son, et cetera.

According to Ursinus (1886:177), it is explicit in the testimony of the Old and New Testaments that in the one essence of God, three persons (Father, Son and Holy Spirit) exist through their characteristics and, though significantly different, they are equal in essence and in eternity. ${ }^{6} \mathrm{He}$ (Ursinus ibid:177178) also makes the point, without specifying texts, that there are places in the Bible:

- where the three persons are named Jehovah and God

- where the three are ascribed the same fullness of divine essence

- that attribute the same properties and perfections of divine nature to the three persons

- that attribute to the three the same works unique to the Godhead

- where the three are accorded equal honor, worship and homage.

Ursinus (1886:178ff.) also addresses various errors that existed, such as those associated with Samosatenus and Servetus (that they are truly persons) and Sabellius (that they are distinguished), as opposed to Arius, Eunomius and Macedonius (that they are equal and of the same essence). Some of these errors are still prevalent today (cf. inter alia Garlow \& Jones 2004:81-98; Jones 1992:26-28).

Finally, Ursinus (1886:183) engages the question of why it is essential that the doctrine of the Trinity is maintained. The answer is twofold, namely because of the glory of God (so that the true God is distinguished from idols) and also for our comfort and salvation.

Olevianus (1995:14-20) gives a 'pastoral' approach in his exposition of Lord's Day 8 and does not give as thorough a theological explanation as Ursinus does. He especially deals with the consequences of what happens to those who do not accept the doctrine of the Trinity. This approach confirms the view of Steenkamp (1989:619) that Olevianus had a particular interest in church discipline. Regarding question and answer 25 , he does deal with the matter of the divinity of the Son and of the Holy Spirit (Olevianus ibid:17-20).

\section{Lord's Days 5, 6 and 17}

From the above (see point 2 under 'Introductory remarks') it is suggested that views on the divinity of Christ and his resurrection from the dead directly affect the doctrine of the Trinity. For this reason some attention will be given to what the Church confessed about this in the HC.

In answer 15 it is stated that the true mediator and saviour must be a true and righteous man, yet more powerful than all creatures, that is at the same time true God. On the question

6. He refers amongst others to Genesis 1:2-3; Psalm 33:6; Matthew 28:19; John 14:26, 15:26; 1 John 5:7; Titus 3:5-6; Ephesians 2:18; 2 Corinthians 13:13; Galatians 4:6. 
why he must simultaneously be true God (question 17), the answer is: 'To take on, through the power of His divinity, the burden of the wrath of God in his human nature so as to gain for and restore unto us righteousness and life' (GKSA 2001:37). This mediator is our Lord Jesus Christ (answer 18) and this we know from the holy gospel (answer 19, GKSA ibid:37). Here, the HC, in a striking manner, gives the scriptural grounds for this profession.

In response to question 17, Ursinus (1886:114-115) states that man alone would have been crushed should he have taken the weight of God's wrath on him. Therefore the mediator would have to be imbued with infinite power, and thus be God, to adequately bear immeasurable suffering, infinite despair and total destruction. The sufferings of the mediator therefore had to be of infinite value as compared to eternal sufferings, to ensure proportionate equity between sin and punishment. In time, these sufferings had to be finite, because the saviour would not always remain in death, but emerge from it so he could complete the full measure of redemption. The ransom of the mediator had to be of infinite value, so that it would be a sufficient and adequate price to redeem our souls. In other words, so that in God's judgment it would be sufficiently powerful to deal with our sin and recover righteousness and life that was lost to us.

Whoever denies the divinity of Christ cannot simultaneously profess any redemption, because then there is no mediator and God's wrath against sin remains.

That Jesus Christ our Lord is the mediator is clear from the comparison of the revelations and prophecies in the Old Testament with their outcome in the New Testament. It is likewise evident from the works and miracles of Christ himself, as well as clear testimonies of the scriptures, such as 1 Timothy 2:5 and 1 Corinthians 1:30 (Ursinus 1886:118-119).

HC articulates old church dogma here, simply because, according to the authors, it is faithful to scriptural teaching (Klooster 1990):

The issues stated so briefly and simply in these $Q$ and A's were the great issues faced by the early Christian church as it brought the gospel to the pagan world. Who is this Jesus who is preached? How does he differ from other humans? Is he truly God? These were the issues that church leaders struggled with in the great ecumenical councils of Nicea (325), Constantinople (381), Ephesus (431) and Chalcedon (451). The decisions of those ecumenical councils truly echo the Scriptures and are found in all the orthodox Christian creeds and confessions. The gospel is the gospel of Jesus Christ, God's incarnate Son, the second Person of the Trinity. (p. 25)

Klooster could have added that the decisions of the ecumenical councils also served to answer heresies of people like Celsus, Arius and the Ebionites (cf. Coetzee 2013).

Lord's Day 17 (question and answer 45), in particular, deals with the resurrection of Christ in a specific and unique manner. There is no question of dispute regarding the resurrection as it proceeds from a factual acceptance of the event. The matter is dealt with from the perspective of the usefulness of the resurrection for believers. This unique way of dealing with one of the great truths of salvation is probably explained by the fact that it was not an issue questioned or denied in the sixteenth century, or during the time when the Apostolicum was formulated. ${ }^{7}$ It was not part of the theological debate as it is today. Furthermore, it should be explained by the fact that in the $\mathrm{HC}$ we have to do with a confession that proceeds from and is based on the revelation of scripture.

Yet, it is of note that Ursinus (1886:322-324) does deal with the fact of the resurrection (history) before he attends to its fruit - not to argue against other views, but merely to give an account of what happened according to Scripture. Christ, God and man rose in the same body he died with. He who was truly dead, revived, his soul called back to his body, and on the third day after the funeral, in accordance with the Scriptures, gloriously emerged from the grave by the power and proficiency of the Father, as well as his own (Ursinus ibid:322).

We also find in answer 45 a clear reference to answer 17 about the divinity of Christ. By the power of his divinity, he bore the brunt of the wrath of God in his humanity and appropriated righteousness, obtained and returned to us (answer 17). He conquered death by his resurrection, so that he could make us partakers of righteousness (answer 45).

In his exposition of Lord's Day 17, Olevianus (1995:72-74) focuses mainly on the benefits apportioned to believers by the resurrection of Christ.

\section{Lord's Day 20}

Sunday 20 (question and answer 53) confesses that the Holy Spirit with the Father and the Son is true and eternal God. This confession forms an integral part of the doctrine of the Trinity. Ursinus (1886) puts it as follows:

The Holy Spirit is the third person of true and eternal deity, proceeding from the Father and the Son, together they are eternally equal and the same, sent by both to occupy the hearts of the elect unto a holy and eternal life. (p. 375)

In his exposition, Ursinus elaborates and goes at length to reference a large number of texts from Scripture, so as to show that the Holy Spirit is a person: that he differs in person from the Father and the Son, but is equal to both the Father and the Son and one in essence with them (cf. Ursinus 1886:375384). At the same time, he answers contrary opinions, such as those of sabellianism (Ursinus ibid:377).

Olevianus (1995:90-95) focuses mainly on the work ('office') of the Holy Spirit.

\section{The doctrine of the Trinity in the rest of the Heidelberg Catechism}

When the HC particularly focuses on references to the Trinity or to the respective persons, it is worth noting that the

7.The doctrines of the divinity and resurrection of Christ were never in jeopardy neither amonst the divity and resurrection of Christ were never in jeopardy neither anongst the churches of the Reformation, nor within the Roman Catholic Church. Today, however, even churches within a Reformed tradition find it a significant point of theological controversy that seriously affects the confession (cf. inter alia Bosch 2009; Coetzee (2013); and the section below titled 'South African context'). 
doctrine of the Trinity appears as a golden thread running through the $\mathrm{HC}^{8}$ and then the emphasis is generally on what God in the Trinity does. Simultaneously, there is the unmistakable appearance of evidence of the Christocentric nature of the Catechism. Verboom (2012:115) speaks of a trinitarian interpretation of the Word in the HC. At the same time, he declared unequivocally (Verboom ibid:115): 'The beating heart of the HC is formed by its Christology.' The $\mathrm{HC}$ is about the acts of God in and through the person and work of Jesus Christ (Korn 1963:94).

Herrenbrück (1965:58) shows that, by virtue of its tripartition, the $\mathrm{HC}$ reflects an underlying trinitarian end (bestimmt). It speaks on numerous occasions of God as undifferentiated. From its beginning we find recourse to traditional trinitarian vocabulary (Begriffsprache) (Herrenbrück ibid:51). When the $\mathrm{HC}$ is seen as a whole, Herrenbrück (ibid:58) states: 'The Mitte der dreieinige Gott selber, geoffenbart in Jesus Christ als Vater, Sohn und Heilige Geist Ihrem dreifacheinen Work am Menschen' [The centre of the triune God himself, revealed in Jesus Christ as Father, Son and Holy Spirit and their threefold work to man]. ${ }^{9}$

\section{South African context}

Regarding the South African context, it is especially the views of Spangenberg et al., Van Aarde and Müller that are controversial and should be evaluated in light of the confession. Spangenberg distinguishes between a historical Jesus, a Jesus found in New Testament 'narrative' and a dogmatic Jesus (Spangenberg, Botha \& Jacobs 2009:6, 368). Spangenberg et al. (ibid:147; Spangenberg 2011) accords authority to extra-biblical sources, such as the gospel known as ' $Q$ ' and the gospel of Thomas (Spangenberg et al. ibid: 150-152; Spangenberg 2011). Based upon the authority of these two sources, Jesus is regarded as mere man (Spangenberg et al. ibid:158). He therefore categorically rejects the divinity of Christ and the doctrine of the Trinity (Spangenberg et al. ibid:352, 362). According to him, there is no resurrection, whether of Jesus or us (Spangenberg 2011).

Van Aarde declared himself in favour of a Christology 'from the side' (Van Aarde 2001):

In this investigation, the issue is how Jesus would have been experienced by his contemporaries rather than how his later followers interpreted his words and deeds. The interpretation from a post-Easter faith perspective was filtered through experiences of resurrection appearances. (p. 14)

For Van Aarde, Jesus is God, but not necessarily in the classic ontological sense (Van Aarde 2001:21). His contribution to the historical Jesus research is that Jesus was a fatherless figure who called God his father (Van Aarde ibid:146). 'Records show he was born out of wedlock. A father figure was absent in his life' (Van Aarde ibid:77). This view of Van Aarde corresponds with that of Celsus (cf. Coetzee 2013).

8. Refer to the following questions and answers, along with those which have already been addressed above: $31,40,70,86,115,123$.

9.In the light of this, it is puzzling that Jonker (1994:99) speaks of 'a lack of a Trinitarian foundation'.
Julian Müller's position on the resurrection of Jesus is that he refuses to commit affirmatively to the question of whether Jesus rose bodily from the dead and that his tomb is empty (Müller 2011:75). He will unequivocally answer 'yes' to the question of whether Lazarus' tomb was empty, because the corpse of Lazarus was alive in the 'narrative'. A risen body cannot but leave behind an empty tomb. This is definitely not how we think about the resurrection of Jesus. To think in terms of 'Lazarus categories' about Jesus' resurrection would denude the significance of Jesus' resurrection immeasurably. Where we do agree with Müller, is that the concept of 'spiritual body' in 1 Corinthians 15 has immense and unimaginably rich meaning (cf. Müller ibid:77). The spiritual body is, however, still a body (soma).

Chapters 1, 3, 6, 8, 9 and 10 in König's book deals insightfully with the views of Spangenberg, Van Aarde and Müller to conclude that their views threaten the gospel (König 2009:17).

\section{Summary}

In concluding this section, it may be stated that the God confessed in the HC is the triune God (Father, Son and Holy Spirit) as he made himself known in Jesus Christ: in his Word, in his covenant relationship (actions) with humankind, and in particular with his elect. He is the 'only true God' of the first commandment (Lord's Day $34 \mathrm{HC}$ ). In the closest and most logical coherence with this, the HC confesses the deity of Christ and of the Holy Spirit. The HC proceeds from the premise of the historical, bodily resurrection of Christ from the dead. 'Der Heidelberger nicht nur trinitarisch begründet befindet sich auch ständig trinitarischer Bewegung' [The Heidelberger is not only founded Trinitarian, but find itself also in a trinitarian movement (process)] (Herrenbrück 1965:59). Its trinitarian approach forms a 'polyphonic love song' (Verboom 2012:116).

This also applies to the 'doctrines of creation and providence', or the relationship of the Triune God to creation, which will be the focus of attention in the next section. In the HC, faith in God the creator and sustainer does not stand alone, but in the vervlechting [engagement or being intertwined] with the Trinity (Verboom 1996:90).

\section{The triune God and creation Introduction}

Barth (1948:51) calls the relation of God to creation the 'Rückgrat der christlichen Lehre' [backbone of the Christian doctrine]. In addition, it is inextricably linked with the knowledge of our salvation in Jesus Christ (Barth ibid:52).

\section{God as creator}

The HC proceeds from the scriptural premise that God is the creator. Lord's Day 3 (question and answer 6) already treated the matter about how God created man, namely good and in his image (GKSA 2001:34). 
The first article of the Apostolicum is dealt with in Sunday 9 (question and answer 26) raising the question (GKSA 2001:40): 'What do you believe when you say: I believe in God the Father Almighty, Maker of heaven and earth?' Barth (1948:53) makes the important observation that it does not ask what you know or what you feel, as Schleiermacher does, but rather what you believe. It is therefore about what God's Word says.

The answer to this question once again brings the soteriological and christocentric nature of the $\mathrm{HC}$ to the fore. The main clause of the answer is (GKSA 2001:40): 'I believe that the eternal Father of our Lord Jesus Christ ... for the sake of His Son Christ is my God and Father'. The rest of the answer is an extension in respect of the eternal Father of Christ, who also is my God and Father. Verboom (1996:91) states that it affirms that we believe that God is true to his creation (word and deed). We can only believe this when in a personal commitment to Jesus Christ, who revealed the Father to us. Faith in God the creator is not dealt with in itself, but as faith in God the Father. Faith in God the creator and Father is also not confessed within itself, but as faith in God, the Father of Jesus Christ. Creation faith is only maintained as faith in the personal God, and translates as faith in God the Father in Jesus Christ. Statements about God are christocentric, whereas statements about Christ are theocentric (Verboom 1996:91).

Herrenbrück (1965:54) also points out that the HC deals with creation christologically and that dominion over the creation and its maintenance is explicitly attributed to the Father of our Lord, Jesus Christ.

Ursinus (1886:186) says the word Father refers in the first place to his relation to Christ, his only begotten Son, and secondly in relation to all creatures in so far as he is the creator and custodian of all things. ${ }^{10}$ Thirdly, it refers to the elect he himself adopted as children and translated through his beloved Son into his beloved.

He is almighty: he can bring about everything he wants, even what he does not want, as long as it is not contrary to his nature, just as he could have withdrawn Christ from the dead, but did not. He can effortlessly accomplish all things. He alone has the power to operate all things and is also the origin of the ability all creatures have. He is all-powerful and wants to manage all things unto my salvation (Ursinus 1886:187).

To believe in him as creator, means to believe that he is the creator of all things, that he maintains and manages all things by his providence, that he created me and made me an object of his mercy unto salvation in Christ, that he will bring me to salvation through a peculiar providence and mercy that he shows unto his elect, and that he created all other things for our sakes so they would serve towards the welfare of his church and to the praise of his glory (Ursinus 1886:187-188). He created through the Son and the Holy Spirit (Ursinus ibid:191-192, citing Jn 1:3, Gn 1:2 \& Job 33:4).

$10 . T h$ is is a very important comment from Ursinus.
Besides Genesis 1 and 2, Ursinus (1886:189) refers to the following passages as evidence that the world was created by God: Psalms 33:6, 9, 104, 113, 124, 136 and 146, Isaiah 44, Job 38 and 39, and Acts 4:17. In addition, he also developed a comprehensive doctrine of creation on the basis of three questions (Ursinus ibid:188-196):

- Did God create the world?

- How did he create?

- Why did he create?

Regarding the omnipotence of God, Olevianus (1995:22) declares that it is powerful, effective and active. We may therefore submit ourselves in true faith to such a powerful, caring Father whose hand and power controls all things and whose power no one can resist. With reference to texts like John 10:28-30 and Romans 8:38-39, Olevianus (ibid:22) stated: 'Since then, we have a covenant and eternal reconciliation with the almighty God, it is certain that no creature's might can do us harm.

According to Olevianus (1995:22), if we think of the creation of God, our faith is strengthened, because we know that we do not have a covenant with an unknown God, but with a God who daily gives himself to us to be, as it were, touched and tasted; citing Acts 17:27-28 and Psalm 34:8.

\section{God as sustainer and ruler}

Lord's Day 10 (question and answer 27 \& 28) is closely associated with Sunday 9. The Father of our Lord Jesus Christ, who created everything out of nothing, is our almighty God and Father, the one who sustains and governs everything by his providence.

Olevianus gives a detailed exposition of the doctrine of providence. Firstly, we can be absolutely sure that everything takes place according to God's counsel or decision and not by chance (Olevianus 1995:24). Secondly, the providence of God extends to include my life and to ensure my protection (Olevianus ibid:26). Thirdly, God's rule extends to all the people and creatures we encounter (Olevianus ibid:29). This also applies to angels and demons. The latter is employed by God in such a manner that without him they could not stir or move (Olevianus ibid:29-30). Finally, we have the resources that God has provided, which we use in faithful obedience, and not because we do not trust God, but so as not to erroneously trust created things (Olevianus ibid:30).

Ursinus also developed an extensive doctrine of providence (Ursinus 1886:196-223). He sees it as a 'persistent' creation, because its government is the maintenance of all created (Ursinus ibid:196). Just as nothing could have come into being unless God created all things in like manner, nothing can maintain its existence for one moment unless God keeps it by his providence and management (Ursinus ibid:196-197). As evidence from the Scriptures, Ursinus refers to texts like Acts 17:23, 24, Matthew 10:29, 30 and Ephesians 1:11 (Ursinus ibid:197). Providence for Ursinus is the eternal free, immutable, altogether wise, righteous and good intention 
of God, whereby he brings about good in all creatures and allows evil to be done, and everything, both good and evil, is managed to his honour and the salvation of the elect. In this regard, there is evident agreement with the position of Calvin (Inst.1.17.1) that God's providence is in a sense peculiarly applicable to the church (cf. Coetzee 2010). ${ }^{11}$

Ursinus (1886:210-214) gives a large number of scriptural quotations pertaining to matters that, in his opinion, are subject to God's providence.

Finally, Ursinus states with great certainty that all foundations of religion and piety are torn away if we do not cling to the providence of God, because without that we cannot be patient in adversity, grateful in prosperity or have confidence with regard to the future (Ursinus 1886:223).

Verboom (1996) also pays specific attention to Lord's Day 10. He describes the covenant idea as the cement for the structure of Lord's Day 10, although the word covenant is not used (Verboom ibid:92). The covenant is the gracious relation of God to people for Jesus' sake. If you see providence in this light, it is a very comforting doctrine (Verboom ibid:92). The things that happen in the world and in my personal existence would lose all sense if the hand of God was not in that - the hand that I may know in Jesus Christ as the hand of my Father (Verboom 1996:93). Things do not happen outside of God. Even in the most incomprehensible of happenings, God wields his hand to turn things for good (Verboom ibid:93). The reference to the Father's hand of God, is not just an image or an anthropomorphism. It is much more (Barth 1948:55). 'Wenn in der Schrift von der Hand Gottes gesprochen wird, immer seine Rechte gemeint' [Whenever Scripture speaks of the hand of God, his governance (right) is meant] (Barth ibid:56). Barth (ibid:56) also refers to question and answer 50 of the HC that confesses Christ as seated at the right hand of God as head of his church, and through whom the Father governs all things.

\section{The immanence and transcendence of God}

We may ask all things of the Father and expect everything. We may put all our trust in him (answer 28). Being almighty God, he is able to do it and being a faithful Father, he is willing to do so (answer 26). In a compelling way, both the transcendence and immanence of God may be confessed: in the concrete occurrence of rain and drought, fruitful and barren years, health and sickness, riches and poverty, 'and in all things' (answer 27).

We also see it in the opening statement of the Lord's Prayer and the HC's statement or confession of the same (Sunday 46, question and answer $120 \& 121)$.

It is noteworthy that Ursinus $(1886: 351,354)$, in his exposition of Lord's Day 46, often refers to the creation. God is our Father through the creation (Ursinus refers here to Lk 3:38),

11.Coetzee (2010:160-164) shows that, as far as the doctrine of providence is concerned, there is clear agreement between Calvin's view and the Reformed Confessions. As far as the HC is concerned, the influence of Calvin was probably via his student, Ursinus. and through salvation and sanctification or regeneration (Ursinus ibid:351). We need to behave as children toward the Father - with due reverence becoming children adopted by grace and unworthy of God's blessings. We call upon him as Father, because we have the assurance that he will give us all things that pertain to our salvation, but also for all that we need for our mortal existence (Ursinus refers here to Rm $8: 32$ ). We also call upon him in remembrance of creation (cf. Ursinus ibid:351).

Christ clearly commanded we call upon him as 'our father who is in heaven'. He is heavenly Father. Heaven, according to Ursinus (1886:354), indicates the dwelling place of God. Whilst immeasurable, God is omnipresent. It is said that he dwells in heaven, because the revelation of his glory is more evident there than in the world and he reveals himself more evidently there.

When Christ commands us to address God as our Father in heaven, he does so to highlight the contrast between earthly fathers and this Father, and to set him apart from earthly fathers. We must think of him as Father who is no earthly father, but a heavenly Father who reigns everywhere with heavenly glory and majesty, and stands at the head of all things and the whole world that was created through him and is providentially managed by him. He is free from all decay and change. He reveals himself especially in the heavens in the presence of angels, revealing the Father that he is: how good, how powerful and all-sufficient (Ursinus 1886:354).

We must call to him in this manner by virtue of the trust we have that he will hear us. He is our Father in heaven, clothed with omnipotence and able to give us the gifts we ask for. Finally, we call unto him out of reverence. Our heavenly Father is such a great God, whose rule may relegate soul and body to hell. We should therefore honour his great majesty and approach him in the most humble submission of body and soul (Ursinus 1886:354). We may have no earthly thought of his heavenly majesty (answer 121).

It is precisely this image of God of the HC that is apparently no longer acceptable for someone like Julian Müller. He (Müller 2011:152) is of the opinion that the 'old language' does not adequately meet modern man's way of thinking about God and the universe. According to Müller, the tension between this modern worldview on the one hand and our religious concepts on the other is a source of great despair amongst Christians in the present day. His experience is that thinking people alienate themselves more and more from the kind of religion that is generally and popularly espoused in churches and articulated in the press (Müller ibid:112-113).

The growing consensus among scientists and ordinary people about the workings of nature and the origin of life for example, just do not fit in with the standard concepts of God, creation and relationship between man and God. (Müller 2011:113, author's own translation)

Müller personally abandoned the theistic God and, though he feels relieved, he is ambivalent about the matter (Müller 2011): 
The God who entered my life now is not so easy to capture by means of words. Content of familiar concepts such as 'Father,' 'Almighty,' 'Above', 'Higher Hand,' 'Mover', 'God's will', 'Providence' and many more just do not fit in with the God I got to know because God is no longer above and beyond and masculine, strong and in control. For me God is now much more the Possible, the Unexpected, the Stranger, the Marginalized, the Thought, the Reality, the Movement, and the Life. (p. 40, author's own translation)

Müller therefore sees himself as a post-theist and formulates his image of God in terms of panentheism (Müller 2011:41).

Apparently, Müller's point of departure proceeds from the viewpoint of modern man, science and the modern worldview. In contrast, Reformed theology takes its point of departure from God's Word. The question is what God says in his Word about himself and of his relationship to humankind and created reality. The question then is whether the $\mathrm{HC}$ and other confessions follow suit in emulating the language of the Word.

Churches in the reformed tradition have always accepted the confessions (quia), because they are in accordance with the Word. Believers throughout the centuries were comforted by the knowledge that we do not have dealings with a distant, impersonal God, but with a Father in the richest sense of the word, who delivered us in Christ and adopted us as his children and who, by his Spirit, indwells and works in us. This Father is God almighty, transcendent, 'in heaven', elevated above, outside of his creation, and in no way part of it - not by way of creation or creatureliness. But at the same time he is immanent: directly involved and intense, governing, sustaining and involved in every breath, every blink of an eye and every hair that falls. Can there be a different and greater comfort for people today?

\section{Summary}

As far as the scope of this article is concerned, the relationship between God and creation may be summarised as follows.

In agreement with the church of the first centuries, the $\mathrm{HC}$ confesses and teaches a personal God, the Father of Jesus Christ who, for the sake of Christ, is the Father of the elect. The confession is thus determined by its christocentricity and soteriology. This God is the almighty creator of heaven and earth. He lives in a covenant relationship with his creation, which he sustains and governs at every moment. He is both transcendent and immanent.

\section{Conclusions and closing remarks}

1. The HC, along with the other Reformed confessions, has stood the test of time reflective of the essence of the church. To date, no point of conflict with Scripture has been shown.

2. This confession is therefore still part of believers' only comfort in life and death, and is particularly topical and relevant in terms of the problems of our time.
3. Statements that question or reject the doctrine of the Trinity, deny the divinity of Christ, foster doubts about the historical bodily resurrection of Christ, deny God's creation and providence (for example, by accepting the theory of evolution), or associate God in any way with his creation, are in conflict with this confession. Where such deviant views in this regard are allowed to penetrate theology and the church, it is a sign that the confessional statement is no longer taken seriously. That is deformation.

4. Churches of the reformation and the theological tradition in which we stand, can only maintain their identity where this confession is expressed and maintained as a living confession.

5. Reformed theology is, amongst others, church theology. It is therefore in the service of the church and should serve the church in maintaining its identity and fulfilling its calling.

6. Reformed theology is, amongst others, also confessional theology and should in practice proceed from this paradigm. Where this does not happen, an artificial and untenable separation occurs between faith and science.

\section{Acknowledgments Competing interests}

The author declares that he has no financial or personal relationship(s) that may have inappropriately influenced him in writing this article.

\section{References}

Barth, K., 1948, Die christliche Lehre nach dem Heidelberger Katechismus: Vorlesung gehalten an der Universität Bonn im Sommersemester 1947, Evangelischer Verlag, Zollikon, Zürich.

Beeke, J.R. \& Ferguson, S.B. (eds.), 1999, Reformed confessions harmonized, Baker Books, Grand Rapids, MI.

Bierma, L.D., Gunnoe, C.D., Maag, K.Y. \& Fields, P.W., 2005, An introduction to the Heidelberg Catechism: Sources, history and theology, with a translation of the smaller and larger catechisms of Zacharias Ursinus, Baker Academic, Grand Rapids, MI.

Bosch, P.B., 2009, 'Die opstanding van Jesus Christus: 'n Histories-sistematiese ondersoek', PhD thesis, Theology Department, University of Pretoria.

Calvin, J., 1966, Institutes of the Christian religion, transl. H. Beveridge, Eerdmans, Grand Rapids, MI.

Clayton, P., 2000, The problem of God in modern thought, Eerdmans, Grand Rapids, MI.

Coetzee, C.F.C., 2010, 'The doctrine of providence in the Institutes of Calvin - still relevant?', In die Skriflig 40(3), 145-166.

Coetzee, C.F.C., 2013, 'Ho eschatos: The eschatological Christ and the future of reformed theology', In die Skriflig 47(1). http://dx.doi.org/10.4102/ids.v47i1.580

Cooper, J.W., 2007, Panentheism: The other God of the philosophers - from Plato to the present, InterVarsity Press, Nottingham.

Dawkins, R., 2006, The God delusion, Houghton Mifflin, Boston, MA.

Du Toit, B., 2000, God? Geloof in postmoderne tyd, CLF Uitgewers, Bloemfontein.

Engelbrecht, B.J., 1989, " $n$ Vergelyking tussen die teologie van die Nederlandse Geloofsbelydenis en die Heidelbergse Kategismus', Hervormde Teologiese Studies 45(3), 626-654

Esterhuyse, W., 2009, God en die gode van Egipte: In die voetspore van die onsienlike, Lux Verbi, Wellington.

Ferreira, I.W., 2009, 'Die ontwikkeling van die menslike bewussyn: Die postmoderne vraag na God', Teologiese Studies/Theological Studies 65(1), 357-362. http:// dx.doi.org/10.4102/hts.v65i1.178

Garlow, J.L. \& Jones, P., 2004, Cracking Da Vinci's code, Victor, Colorado Springs, CO.

Gereformeerde Kerke in Suid-Afrika (GKSA), 2001, Psalmboek: Die berymde en omgedigte Psalms en ander Skrifberymings in gebruik by die Gereformeerde Kerke in Suid-Afrika, N.G. Kerk-Uitgewers, Wellington. 
Herrenbrück, W., 1965, 'Der Trinitätstheologische Ansatz des Heidelberger Katechismus', in W. Herrenbrück \& U. Smidt (eds.), Warum wirst du ein Christ genannt? Vorträge and Aufsätze zum Heidelberger Katechismus im Jubiläumsjahr 1963, pp. 48-66, Neukirchener Verlag des Erziehungsvereins, Neukirchen.

Jacobs, P., 1959, Theologie reformierter Bekenntnisschriften, Neukirchener Verlag, Neukirchen.

Jones, P., 1992, The gnostic empire strikes back: An old heresy for the New Age, P\&R, Phillipsburg, NJ.

Jonker, W.D., 1994, Bevrydende waarheid: Die karakter van die gereformeerde belydenis, Hugenote Uitgewers, Wellington.

Klooster, F.H., 1965, 'The Heidelberg Catechism: An ecumenical creed?', Bulletin of the Evangelical Society 8(1), 23-33.

Klooster, F.H., 1990, A mighty comfort: The Christian faith according to the Heidelberg Catechism, CRC Publications, Grand Rapids, MI.

Klooster, F.H., 1994, 'Calvin's attitude to the Heidelberg Catechism', in W.F. Graham (ed.), Later Calvinism: International perspectives, pp. 311-331, Sixteenth Century Journal Publishers, Kirksville.

König, A., 2009, Die evangelie is op die spel: Die verwarring oor die Bybel, en oor Jesus se lewe, sterwe en opstanding. ' $n$ Alternatief op liberalisme en fundamentalisme, Lux Verbi, Wellington.

Korn, W.E., 1963, 'Die Lehre von Christi Person und Werk', in L. Coenen (ed.), Handbuch zum Heidelberger Katechismus, pp. 91-104, Neukirchener Verlag, Neukirchen.

Moltmann, J., 1985, God in creation: A new theology of creation and the Spirit of God, transl. M. Kohl, Fortress Press, Minneapolis, MN.

Müller, J., 2007, "n Nuwe verstaan van God vir 'n nuwe tyd?', Bylaag tot Beeld, 13 Oktober, pp. 8-9.

Müller, J., 2011, Om te mag twyfel: 'n Gelowige se reis, Tafelberg, Cape Town.

Muller, P. (ed.), 2002, Die nuwe hervorming, Protea Boekhuis, Pretoria.

Olevianus, C., 1995, A firm foundation: An aid to interpreting the Heidelberg Catechism, transl. L.D. Bierma (ed.), Baker Books, Grand Rapids, MI.

Schulze, L.F., 1993, 'Calvyn en die Heidelbergse Kategismus', In die Skriflig 27(4), 487-499.

Schulze, L.F., 1994, 'Die teologiese wortels en struktuur van die Heidelbergse Kategismus: 'n Oorsig', Hervormde Teologiese Studies 50(1-2),194-210.
Spangenberg, S., Botha, P. \& Jacobs, M., 2009, Jesus van Nasaret, Griffel Media, Cape Town. http://dx.doi.org/10.4102/hts.v67i1.874

Spangenberg, I.J.J., 2011, 'Opstandingsverhale en opstandingsdogma', HTS Teologiese Studies/Theological Studies 67(1), 874.

Steenkamp, J.J., 1989, 'Ursinus, die opsteller van die Heidelbergse Kategismus, Olevianus en die Heidelbergse teologie', Hervormde Teologiese Studies 45(3), 611-625.

Stoker, H.G., 1994, 'Die Jehovah-getuies: 'n Onchristelike kulte?', PhD thesis, Dept. Sentrale Publikasies, PU vir CHO, Potchefstroom.

Ursinus, Z., 1886, Verklaring op den Heidelbergschen Catechismus, transl. C. van Proosdij, Zalsman, Kampen.

Van Aarde, A., 2001, Fatherless in Galilee: Jesus as child of God, Trinity Press International, Harrisburg, PA.

Van den Berg, E., 2012, 'God als Vader: De verhouding tussen de catechismusleerling en God als Vader binnen de gereformeerde prediking in de zeventiende eeuw', ThM dissertation, Dept. of Systematic Theology, Universiteit Utrecht.

Van Genderen, J. \& Velema, W.H., 2008, Concise reformed dogmatics, transl. G. Bilkes \& E.M. van der Maas, P\&R, Phillipsburg, NJ.

Van 't Spijker, W. (ed.), 2009, The church's book of comfort, transl. G. Bilkes, Reformation Heritage Books, Grand Rapids, MI. PMid:19260425

Van 't Spijker, W., 2012, email, 15 September, wvantspijker@wxs.nl

Van Wyk, J.H., 2003, 'Die nuwe hervorming: Verwagting of verydeling?', In die Skriflig 37(3), 345-373. http://dx.doi.org/10.4102/ids.v37i3.473

Verboom, W., 1996, De theologie van de Heidelbergse Catechismus: twaalf thema's: de context en de latere uitwerking, Boekencentrum, Zoetermeer.

Verboom, W., 2010, 'Bezielde geloofsverantwoording', Theologica Reformata 53, $156-161$.

Verboom, W., 2012, 'The Christology in the Heidelberg Catechism and in the Canones of Dordt', in E. van der Borght \& P. van Geest (eds.), Strangers and pilgrims on earth: Essays in honour of Abraham van de Beek, pp. 115-128, Brill, Leiden.

Vorster, J.H., 2006, 'Waar is jou God? Relevante insigte in die Westers-Christelike tradisie rakende hedendaagse bevraagtekening van God se teenwoordigheid', Teologiese Studies/Theological Studies 62(1), 175-206. http://dx.doi. org/10.4102/hts.v62i1.343

Wentsel, B., 1987, God en mens verzoend: Godsleer, mensleer en zondeleer, Kok, Kampen. 